\title{
Quantifying sponge host and microbial symbiont contribution to dissolved organic matter uptake through cell separation
}

\author{
Meggie Hudspith ${ }^{1, *}$, Joëlle van der Sprong ${ }^{1}$, Laura Rix ${ }^{2}$, Dóra Víg ${ }^{1}$, Jorien Schoorl ${ }^{1}$, \\ Jasper M. de Goeij ${ }^{1,3}$ \\ ${ }^{1}$ Department of Freshwater and Marine Ecology, Institute for Biodiversity and Ecosystem Dynamics, \\ University of Amsterdam, 1098 XH Amsterdam, Netherlands \\ ${ }^{2}$ Australian Centre for Ecogenomics, School of Chemistry and Molecular Biosciences, University of Queensland, \\ Brisbane 4072, Queensland, Australia \\ ${ }^{3}$ CARMABI Foundation, Piscaderabaai z/n, PO Box 2090, Willemstad, Curaçao
}

\begin{abstract}
Sponge-microbe symbioses underpin the ecological success of sponges in many aquatic benthic ecosystems worldwide. These symbioses are often described as mutually beneficial, but identifying positive symbiotic interactions and quantifying the contribution of partners to physiological processes is challenging. For example, our understanding of the relative contribution of sponge cells and their microbial symbionts to the uptake and exchange of dissolved organic matter (DOM) - a major component of sponge diet - is limited. Here, we combined hostsymbiont cell separation with pulse-chase isotopic labelling in order to trace the uptake of ${ }^{13} \mathrm{C}$ - and ${ }^{15} \mathrm{~N}$-enriched DOM into sponge cells and microbial symbionts of the encrusting Caribbean sponges Haliclona vansoesti and Scopalina ruetzleri, which are low microbial abundance (LMA) species. Sponge cells were responsible for $>99 \%$ of DOM assimilation during the pulse-chase experiment for both sponge species, while the contribution of symbiotic microbes to total DOM uptake was negligible $(<1 \%)$. Nitrogen derived from DOM was translocated from sponge cells to microbial cells over time, indicating processing of host nitrogenous wastes by microbial endosymbionts. Thus, host cells drive DOM uptake in these species, while microbial symbionts may aid in the recycling of host-waste products. Our findings highlight the ability of sponges to derive nutrition by internalizing dissolved compounds from their environment and retaining nutrients via host-microbe interactions.
\end{abstract}

${ }^{*}$ Corresponding author: m.r.hudspith@uva.nl

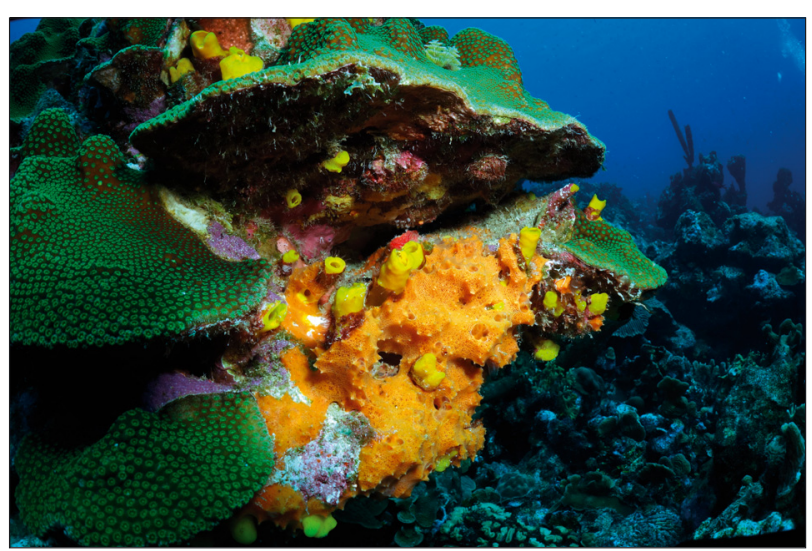

In the coral reef sponge Scopalina ruetzleri, sparse microbial symbionts recycle host waste-products, but sponge cells drive dissolved organic matter uptake.

Photo: Benjamin Mueller

KEY WORDS: Nutrient translocation - Animalmicrobe symbiosis $\cdot$ Sponge holobiont $\cdot$ Stable isotope tracer $\cdot$ Cell separation

\section{INTRODUCTION}

Symbioses are widespread in nature and are defined in the broadest sense as intimate and enduring associations between different organisms, which lie on a continuum spanning mutualistic to parasitic

() The authors 2021. Open Access under Creative Commons by Attribution Licence. Use, distribution and reproduction are unrestricted. Authors and original publication must be credited. 
interactions (Paracer \& Ahmadjian 2000). Mutualistic symbioses are those where both partners receive benefits in a reciprocal manner, and they underpin the ecological success of numerous foundational species and ecosystem engineers (Smith \& Read 2010, van der Heide et al. 2012). Well-known examples include the symbiosis between phototrophic unicellular algae and reef-building corals (Muscatine \& Porter 1977) and the association between tube worms and their chemoautotrophic symbionts in deep-sea hydrothermal vent communities (Cavanaugh et al. 1981). Such mutualisms are pivotal in that they shape community structure and function and affect the ecology and evolutionary trajectory of the partnership at the individual level (Hay et al. 2004). Identifying and quantifying the costs and benefits of symbiotic interactions is necessary to fully evaluate the influence of symbiont on host ecology (Weisz et al. 2010). This can prove challenging, however, because such interactions are not always easily identifiable or measurable (Leung \& Poulin 2008).

Sponges are ecologically important components of aquatic ecosystems globally and form stable and species-specific symbiotic relationships with complex assemblages of microorganisms (Erwin et al. 2012, Schmitt et al. 2012, Webster et al. 2013, Reveillaud et al. 2014, Thomas et al. 2016). While sponge-microbe interactions span the mutualism-parasitism spectrum, many of the long-term associations between sponges and their symbionts are thought to be mutualistic, or at least commensal (Taylor et al. 2007, Freeman \& Thacker 2011, Thacker \& Freeman 2012). In many cases, these mutualisms are (although likely multifaceted) underpinned by nutrient exchange (Thomas et al. 2016). For example, sponge symbionts can contribute to host nutrition via the translocation of photo- or chemo-synthetically fixed carbon (C) and nitrogen (N) (Wilkinson et al. 1999, Weisz et al. 2010, Fiore et al. 2013, Freeman et al. 2013, RubinBlum et al. 2019) or potentially via the provision of vitamins and amino acids (Fan et al. 2012, Song et al. 2021). In turn, microbial symbionts can utilize hostderived N-rich compounds in the sponge mesohyl (Achlatis et al. 2019, Hudspith et al. 2021), suggesting scavenging of host nitrogenous waste products. These symbioses exemplify the most obvious benefit of mutualism for the host: niche expansion through the acquisition of metabolic pathways restricted to the microbial symbiont (Leung \& Poulin 2008).

Less well-defined are reciprocal benefits of spongemicrobe interactions where both partners can directly metabolize the nutrient in question. Dissolved organic matter (DOM) is the largest reservoir of organic $\mathrm{C}$ in the ocean (Benner et al. 1992) and a major component of sponge diet, constituting 56-99\% of the daily C intake for many shallow-water (reviewed by de Goeij et al. 2017, Morganti et al. 2017, Hoer et al. 2018, Wooster et al. 2019) and deep-sea species (Leys et al. 2018, Bart et al. 2021). Heterotrophic prokaryotes are the primary consumers of marine DOM (Azam et al. 1983, Ducklow \& Carlson 1992), and thus sponge symbionts have long been implicated in DOM cycling in sponges. However, radio- and stableisotope tracer and cell kinetic studies have shown that both sponge cells and microbial symbionts are involved in dissolved organic compound processing (Shore 1971, Wilkinson \& Garrone 1980, de Goeij et al. 2009, Rix et al. 2017, Bart et al. 2020). Recent nanoscale secondary ion mass spectrometry (NanoSIMS) confirmed and visualized that both sponge cells (predominantly choanocytes: sponge filter cells) and microbial symbionts assimilate dissolved organic $\mathrm{C}$ and N (DOC and DON) (Achlatis et al. 2019, Rix et al. 2020, Hudspith et al. 2021). Quantifying the relative contribution of sponge cells and microbial symbionts to DOM assimilation remains challenging, and to date has only been achieved in 2 Mediterranean species with massive growth forms (Rix et al. 2020). Sponge symbionts accounted for $65 \%$ of DOC uptake in the high microbial abundance (HMA) sponge Aplysina aerophoba, but less than $5 \%$ of DOC uptake in the low microbial abundance (LMA) sponge Dysidea avara. Host versus symbiont contribution to heterotrophy was suggested to be driven by their relative biomass in the holobiont rather than single-cell differences in assimilation rates. Whether this applies to sponges with different growth forms (e.g. encrusting, massive) and across different ecosystems, such as tropical coral reefs and deep-sea sponge grounds, is not known. For example, shallow-water and deep-sea encrusting sponges seem to deviate from massive sponges in their ability to process DOM (de Goeij et al. 2017, Bart et al. 2021), although both groups can contribute significantly to local nutrient cycling (de Goeij et al. 2013, Kahn et al. 2015, McMurray et al. 2016).

Here, we investigate the relative contribution of sponge cells and microbial symbionts to DOM assimilation and the subsequent translocation of nutrients by combining stable isotope probing (SIP) with the separation of host cell and symbiont fractions. The dissociation and separation of sponge cells from their symbionts has proved a useful tool to trace nutrient uptake and transfer between autotrophic symbionts and host cells (Freeman \& Thacker 2011, Fiore et al. 2013, Freeman et al. 2013) and to quantify their rela- 
tive contribution to heterotrophy (Rix et al. 2020). Therefore, we optimized the cell separation protocol for 2 common encrusting Caribbean LMA sponges, Haliclona vansoesti and Scopalina ruetzleri, and coupled this process with a pulse-chase experiment to trace the uptake and fate of ${ }^{13} \mathrm{C}$ - and ${ }^{15} \mathrm{~N}$-labelled DOM into sponge cells and microbial symbionts of these sponges. The objectives were to (1) quantify the relative contribution of sponge cells and microbial symbionts to DOM uptake and (2) investigate the transfer of DOM-derived $\mathrm{C}$ and $\mathrm{N}$ between sponge cells and symbionts over time.

\section{MATERIALS AND METHODS}

\subsection{Sponge collection}

This study was conducted at the Caribbean Research and Management of Biodiversity (CARMABI) Research Station on the island of Curaçao during June and July 2018. Individuals of the encrusting sponges (Porifera, Demospongiae) Haliclona vansoesti (0.5-3 cm thick, conulose) and Scopalina ruetzleri (0.5-2 cm thick, conulose) (Fig. 1) were collected from the house reef in front of CARMABI and at the fringing reefs at station 'Buoy 1' $\left(12^{\circ} 07^{\prime} 28.65^{\prime \prime} \mathrm{N}, 68^{\circ} 58^{\prime} 23.23^{\prime \prime} \mathrm{W}\right)$, located on the leeward side of Curaçao. These species were chosen as they are common inhabitants of Curaçaon reefs (Weerdt et al. 1999, Kornder et al. 2021). Sponge individuals were collected from $25-30 \mathrm{~m}$ (H. vansoesti) and 5-15 m (S. ruetzleri) water depth by SCUBA, using a hammer and chisel. Individuals were cleared of epibionts and shaped (including the limestone substrate) to a surface area of approximately $29 \pm 2($ mean $\pm \mathrm{SD}$, throughout the text) and $16 \pm 2 \mathrm{~cm}^{2}$ for $H$. vansoesti and $S$. ruetzleri, respectively $\left(\mathrm{n}=9\right.$ species $\left.^{-1}\right)$. Differences in surface area were due to different tissue densities, as cell separation protocols were optimized using similar cellular biomass between species. Sponges were placed in a coral reef cavity, hanging in wire cages to protect them from sedimentation and predation, at $14 \mathrm{~m}$ water depth for between 7 and $10 \mathrm{~d}$ to recover from collection. Individuals were transferred to the aquaria facilities of CARMABI 24-48 $\mathrm{h}$ prior to incubation to acclimate and were maintained in $100 \mathrm{l}$ flow-through aquaria supplied by reef water pumped in from a depth of $10 \mathrm{~m}$ at $31 \mathrm{~min}^{-1}$. Only healthy specimens with open oscula (visually checked) were used in the experiment.

\subsection{Transmission electron microscopy}

To visualize sponge cells and microbial symbionts of $H$. vansoesti and $S$. ruetzleri (Fig. 1B,D), tissue samples were taken from additional in situ sponge individuals $\left(\mathrm{n}=3\right.$ species $\left.^{-1}\right)$. Sponges were brought to the surface in plastic bags, and tissue samples were taken immediately using a sterile scalpel blade and then transferred to vials containing $2.5 \%(\mathrm{v} / \mathrm{v})$ glutaraldehyde $+1 \%(\mathrm{w} / \mathrm{v})$ paraformaldehyde in PHEM buffer $(1.5 \times$ PHEM [60 mM PIPES, $25 \mathrm{mM}$ HEPES, 10 mM EGTA, 2 mM MgSO$\left.{ }_{4} \cdot 7 \mathrm{H}_{2} \mathrm{O}\right]$ and $9 \%$ [w/v] sucrose, pH 7.4). Samples were fixed for $12 \mathrm{~h}$ at $4^{\circ} \mathrm{C}$, triple-rinsed in PHEM buffer, and secondarily fixed in $1 \%(\mathrm{w} / \mathrm{v})$ osmium tetroxide in Milli-Q water. Samples were dehydrated in a graded series of ethanol $(30,50,70,90,100 \%)$ and infiltrated with EPON araldite using 2:1, 1:1, and 1:2 ethanol/resin mixtures. Samples were infiltrated with $100 \%$ resin
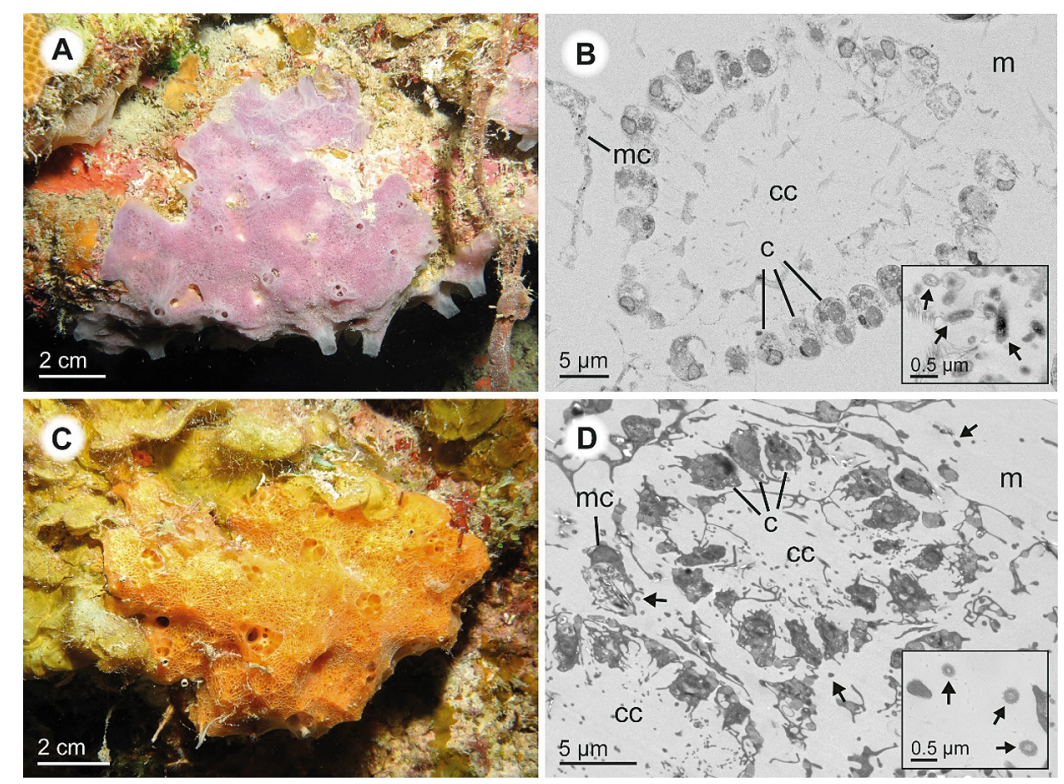

Fig. 1. The encrusting Caribbean sponges (A,B) Haliclona vansoesti and $(\mathrm{C}, \mathrm{D})$ Scopalina ruetzleri. Shown are $(\mathrm{A}, \mathrm{C})$ in situ photographs and $(\mathrm{B}, \mathrm{D})$ transmission electron microscopy images detailing the size and location of sponge cells and microbial symbionts. Sponge cells include choanocytes, which form choanocyte chambers, and cells of the mesohyl matrix. Microbial symbionts (insets) are located extracellularly in the mesohyl. c: choanocyte; cc: choanocyte chamber; m: mesohyl; mc: mesohyl cell. Arrows depict microbial symbionts 
for $3 \mathrm{~h}$, transferred to embedding capsules with fresh resin, and polymerized at $60^{\circ} \mathrm{C}$ for $24 \mathrm{~h}$. Ultrathin (100 nm) sections were cut using a Reichert Ultracut S microtome and transferred to transmission electron microscope (TEM) grids. Sections were stained with uranyl acetate and lead citrate and imaged with a FEI Tecnai T12 TEM at the Electron Microscopy Centre Amsterdam (EMCA).

\subsection{Pulse-chase experiment with isotopically labelled DOM}

A pulse-chase experiment was conducted to test for translocation of DOM-derived $\mathrm{C}$ and $\mathrm{N}$ between sponge cells and symbionts and to quantify the contribution of these cell fractions to DOM assimilation. Isotopically labelled $\left({ }^{13} \mathrm{C}\right.$ and $\left.{ }^{15} \mathrm{~N}\right)$ DOM was extracted from batch cultures of the cosmopolitan diatom Phaeodactylum tricornutum grown on $\mathrm{f} / 2$ medium supplemented with $100 \% \mathrm{NaH}^{13} \mathrm{CO}_{3}$ and $50 \% \mathrm{Na}^{15} \mathrm{NO}_{3}$ (Cambridge Isotope Laboratories; $99 \%$ ${ }^{13} \mathrm{C}, 98 \%{ }^{15} \mathrm{~N}$ ), as per Hudspith et al. (2021). Briefly, diatoms were grown, collected via filtration on a $0.2 \mu \mathrm{m}$ cellulose nitrate filter (Sartorius), and lysed to extract DOM. The resulting solution (representing DOM) was passed successively through a $0.7 \mu \mathrm{m}$ GF/F filter (Whatman) and $0.2 \mu \mathrm{m}$ polycarbonate filter (Whatman). The filtrate was freeze-dried and a subsample taken for C/N content and isotopic composition analysis (see Section 2.5) in order to calculate the amount of DOM to be added to pulse-chase incubations.

Individual sponges were incubated with isotopically labelled DOM during a $3 \mathrm{~h}$ pulse period and then transferred to flow-through aquaria with nonlabelled fresh seawater for a further $21 \mathrm{~h}$. Pulseincubations were conducted in individual 21 airtight incubation chambers (see de Goeij et al. 2013) filled with GF/F filtered (Whatman; $47 \mathrm{~mm}, 0.7 \mu \mathrm{m}$ pore size) seawater. The lids of the chambers were equipped with a magnetic stirring device, ensuring constant water flow during incubation. Isotopically labelled DOM was injected into each chamber using a sterile syringe, and the chambers were closed ensuring no headspace. DOM was added to give a final concentration of $84 \mu \mathrm{M}$ DOC, which is within the range of background DOC concentrations in Curaçao (de Goeij \& van Duyl 2007). Dissolved oxygen (DO) concentrations were measured continuously during the incubations by an optical probe (OXY-4 mini, PreSens) inserted through an airtight port in the chamber lid and served as a proxy for res- piration. DO concentrations decreased linearly over time, demonstrating active pumping of sponge individuals, and did not fall below $11 \%$ of starting concentrations, ensuring sufficient oxygenation of the incubation medium. Incubations were conducted in the dark to prevent photosynthesis by photoautotrophs, and chambers were placed in a flow-through aquarium to maintain ambient reef temperature. At the end of the pulse period, sponges were rinsed in label-free natural seawater and transferred to a flowthrough aquarium for the chase period. Individuals were sampled at $t=0 \mathrm{~h}\left(T_{0}\right)$ and at the end of the pulse $\left(t=3 \mathrm{~h} ; T_{3}\right)$ and chase periods $\left(t=24 \mathrm{~h} ; T_{24}\right) ; T_{0}$ sponges were not incubated and provided background enrichment values. Three replicates were used per species, per time-point. Sampled sponges were rinsed in label-free natural seawater and Milli-Q water, imaged for surface area analysis using the software program ImageJ (http://rsb.info.nih. gov/ij/), and tissue samples were collected using a sterile scalpel blade. A sub-sample of sponge tissue, referred to as 'bulk' tissue, was transferred to preweighed sterile cryovials and stored at $-20^{\circ} \mathrm{C}$ for later stable isotope analysis. The remaining tissue was diced and transferred to a sterile $50 \mathrm{ml}$ Falcon tube filled with ice-cold calcium- and magnesiumfree artificial seawater + EDTA (CMFASW-E; Freeman \& Thacker 2011) and stored at $4^{\circ} \mathrm{C}$ for $1 \mathrm{~h}$ prior to cell separation processing.

\subsection{Separation of sponge and microbial cells}

Sponge cell and microbial fractions were separated by centrifugation using methods adapted from Wehrl et al. (2007), Freeman \& Thacker (2011), and Rix et al. (2020) (Fig. 2), and centrifugation speeds optimized for $H$. vansoesti and $S$. ruetzleri using a Hettich EBA 21 counter-top centrifuge (Andreas Hettich). After $1 \mathrm{~h}$ incubation with CMFASW-E, samples were gently homogenized using a pestle and mortar for $2 \mathrm{~min}$. The resulting cell suspensions were filtered successively through 100, 70, and $40 \mu \mathrm{m}$ cell strainers (Corning Inc.) to remove undissociated cells and spicules, transferred to sterile $50 \mathrm{ml}$ Falcon tubes, and resuspended in $35 \mathrm{ml}$ fresh ice-cold CMFASW-E. Samples were vortexed for $10 \mathrm{~min}$ at $4^{\circ} \mathrm{C}$ and then centrifuged for $4 \mathrm{~min}$ at $1250 \times \mathrm{g}$. Approximately $35 \mathrm{ml}$ of the resulting supernatant containing the microbial cells were transferred to a sterile $50 \mathrm{ml}$ Falcon tube using a pipette and stored at $4{ }^{\circ} \mathrm{C}$; the remaining $5 \mathrm{ml}$ of supernatant was discarded. The resulting sponge pellet was resuspended 


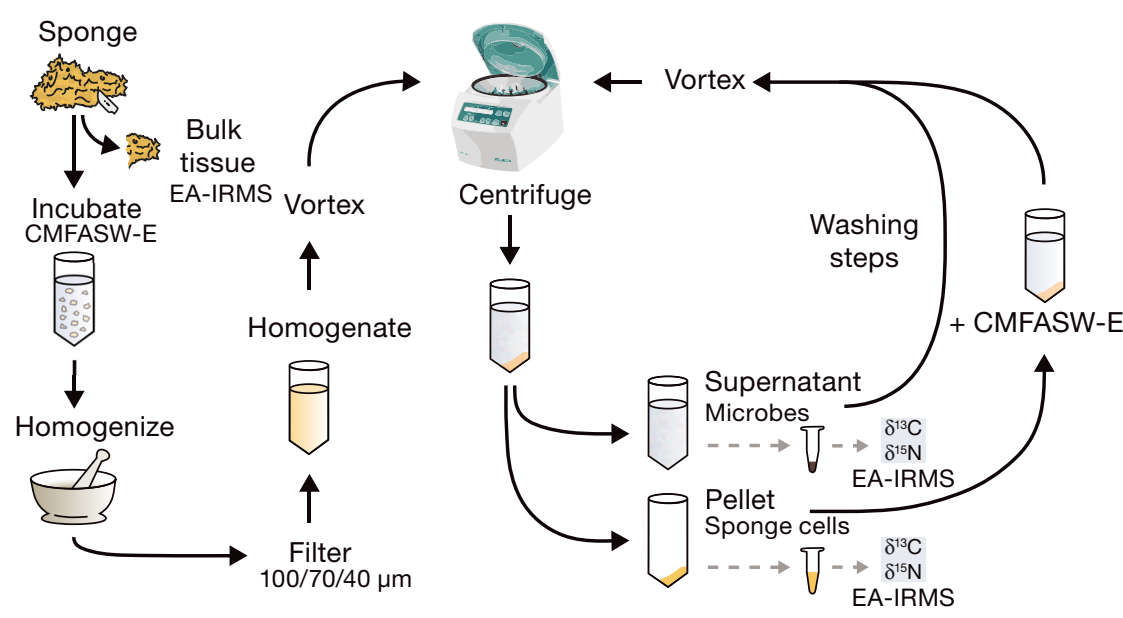

Fig. 2. Schematic overview of the sponge-microbe cell separation process. At the end of the experimental pulse or chase period, sponges were removed from the incubation chambers or flow-through aquaria and tissue samples processed. A subsample of tissue was taken for bulk analysis, and the remaining tissue was homogenized, filtered, and subjected to multiple rounds of centrifugation to separate sponge cells from symbiotic microbes. EA-IRMS: elemental analysis-isotope-ratio mass spectrometry; CMFASW-E: calcium- and magnesium-free artificial seawater + EDTA

in $15 \mathrm{ml}$ of fresh ice-cold CMFASW-E, vortexed for 5 min at $4^{\circ} \mathrm{C}$, and centrifuged for 4 min at either $375 \times g(H$. vansoesti) or $350 \times g($ S. ruetzleri). The supernatant was discarded and $15 \mathrm{ml}$ of fresh icecold CMFASW-E added to the sponge pellet, which was vortexed for $5 \mathrm{~min}$ at $4^{\circ} \mathrm{C}$ and re-centrifuged using the same speeds. This washing step was repeated another 3 times. After the final washing step, the sponge pellet was resuspended in $1 \mathrm{ml}$ of CMFASW, briefly vortexed, and transferred to a sterile $1.5 \mathrm{ml}$ Eppendorf tube. Samples were centrifuged for 6 min at $4000 \times g$ for both sponge species using a Sorvall Biofuge Pico microcentrifuge (Thermo Electron Corporation). The supernatant was removed using a pipette and the sponge pellets stored at $-20^{\circ} \mathrm{C}$ for later stable isotope analysis.

The initial supernatant containing the microbial fraction was centrifuged at $1250 \times g$ for $5 \mathrm{~min}$ for both sponge species. The resulting supernatant was transferred to a clean $50 \mathrm{ml}$ Falcon tube, vortexed, and recentrifuged at the same speed. This step was repeated a further 2 times to pellet the remaining sponge cells from the supernatant. The final microbial supernatant was pelleted by centrifugation (60 min at $3824 \times g$, maximum speed), and the pellet resuspended in $1 \mathrm{ml}$ CMFASW, briefly vortexed, and transferred to a sterile $1.5 \mathrm{ml}$ Eppendorf tube. These samples were centrifuged for 6 min at $10177 \times g$ in the microcentrifuge. The supernatant was removed and the microbial pellets stored at $-20^{\circ} \mathrm{C}$ for later stable isotope analysis.
The purity of the sponge and microbial fractions was determined using epifluorescence microscopy. Prior to the final microcentrifugation steps, subsamples of the sponge and microbial fractions were transferred to sterile $15 \mathrm{ml}$ Falcon tubes pre-filled with artificial seawater and formaldehyde $(2 \%[\mathrm{v} / \mathrm{v}]$ final concentration). Samples were fixed for a maximum of $24 \mathrm{~h}$ and then filtered onto $0.2 \mu \mathrm{m}$ polycarbonate filters (Whatman, $25 \mathrm{~mm}$ ) supported with $0.45 \mu \mathrm{m}$ cellulose nitrate filters (Sartorius, $25 \mathrm{~mm}$ ). Filters were stained with SYBR gold (Invitrogen), mounted, and microbes and sponge cells enumerated for each fraction using a fluorescence microscope (Leica Microsystems) at 1250 and $500 \times$ magnification, respectively. For each sample, 10 fields were counted at each magnification, and the counts were recalculated to give the total number of cells per fraction. Sponge cell fractions were characterized by nuclei of approximately 2-3 $\mu \mathrm{m}$ diameter, while microbial fractions contained small cells $<1 \mu \mathrm{m}$ diameter. The purity of sponge cell fractions was $82 \pm 6 \%$ for $H$. vansoesti and $86 \pm 5 \%$ for $S$. ruetzleri. Microbial fractions contained $99 \pm 1$ and $97 \pm 2 \%$ microbes for $H$. vansoesti and $S$. ruetzleri, respectively. Additionally, the molar C:N ratio of separated sponge cell and microbial fractions for each species were compared using a 1-way permutational analysis of variance (PERMANOVA; see Section 2.6) and found to be significantly different (see Table 1), indicating good separation of the fractions. Samples of the filtered homogenate (pre-centrifugation) were also taken to quantify the total number of sponge cells and microbes in the sponge tissue. These counts were used to calculate the relative contribution of sponge cells and microbes to total DOM uptake.

\subsection{Quantification of ${ }^{13} \mathrm{C}$ - and ${ }^{15} \mathrm{~N}$-enriched DOM uptake into bulk sponge tissue, host cells, and microbial symbionts}

To determine the stable-isotopic enrichment of bulk sponge tissue and separated sponge and microbial cell fractions after a pulse of ${ }^{13} \mathrm{C}$ - and ${ }^{15} \mathrm{~N}$ labelled DOM, C and $\mathrm{N}$ content and isotopic ratios were measured using a Vario Isotope Tube Elemen- 
tal Analyzer (EA; Elementar) coupled with a BioVision isotope-ratio mass spectrometer (IRMS; Elementar) at the Analytical Laboratory of IBED at the University of Amsterdam. Sponge tissue and samples of DOM were lyophilized, weighed, and homogenized. For bulk sponge tissue and DOM, subsamples were processed in 2 ways: they were directly weighed into tin boats (for $\delta^{15} \mathrm{~N}$ and total $\mathrm{N}$ ) and also acidified in $4 \mathrm{M} \mathrm{HCl}$ to remove inorganic $\mathrm{C}$, diluted in Milli-Q water, and lyophilized again prior to weighing into tin boats (for $\delta^{13} \mathrm{C}$ and organic $\mathrm{C}\left[\mathrm{C}_{\text {org }}\right]$ ). Separated sponge and microbial fraction samples were measured simultaneously for $\delta^{13} \mathrm{C}$ and $\delta^{15} \mathrm{~N}$ without acidification due to insufficient tissue for both acidified and non-acidified analysis. These cell fractions may contain negligible amounts of inorganic C (such as limestone substrate), and previous work found acidification of separated cell fractions prior to EA-IRMS was not necessary (Rix et al. 2020). Precision of the IRMS was $<0.11 \%$ for repeated $\delta^{13} \mathrm{C}$ and $\delta^{15} \mathrm{~N}$ measurements of the standard (acetanilide). Isotopic compositions are reported in $\delta$-notation relative to the international standards V-PDB and atmospheric N. DOM incorporation rates were calculated as per de Goeij et al. (2008). Briefly, the difference between the atom fraction of the treatment and background sponges gives the excess fractional abundance (E) of the sample. Total ${ }^{13} \mathrm{C}$ or ${ }^{15} \mathrm{~N}$ incorporation was calculated by multiplying $\mathrm{E}$ by the $\mathrm{C}_{\text {org }}$ or total $\mathrm{N}$ content of the bulk tissue, sponge cells, or microbial cells, which was normalized to the labelling efficiency of DOM to give total tracer incorporation. Final incorporation rates were expressed per biomass unit per hour (i.e. $\mu \mathrm{mol} C$ or $\mathrm{N}_{\mathrm{DOM}} \mathrm{mmol}$ C or $\mathrm{N}_{\text {sponge }}{ }^{-1} \mathrm{~h}^{-1}$ ). C:N molar ratios of separated sponge cell and microbial fractions were calculated by dividing the $\mathrm{C}_{\text {org }}$ content of each fraction by the total $\mathrm{N}$ content.

The relative contribution of sponge cells and microbes to DOM uptake in both sponge species was calculated in a similar manner. Total cell abundances in the homogenate were converted to $\mathrm{C}$ and $\mathrm{N}$ content for each population, assuming $41.2 \mathrm{pg} \mathrm{C} \mathrm{cell}^{-1}$ and $4.7 \mathrm{pg} \mathrm{N}_{\text {cell }}{ }^{-1}$ for sponge cells, and $33.5 \mathrm{fg} \mathrm{C}$ cell $^{-1}$ and $3.4 \mathrm{fg} \mathrm{N}$ cell $^{-1}$ for microbes (values based on the LMA sponge Dysidea avara) (Rix et al. 2020). The $\mathrm{E}$ of the separated fractions was multiplied by the $\mathrm{C}$ or $\mathrm{N}$ content to give total ${ }^{13} \mathrm{C}$ and ${ }^{15} \mathrm{~N}$ incorporation, which was corrected for the labelling efficiency of the DOM to give total tracer incorporation per fraction. This was summed to give total tracer incorporation, and the contribution of each fraction to DOM uptake was expressed as a percentage.

\subsection{Data analysis}

Statistical analysis was performed in Primer V7 (Clarke \& Gorley 2015) using the add-on PERMANOVA+ (Anderson et al. 2008). To test the effect of treatment time-point $(0,3,24 \mathrm{~h})$ on stable isotope enrichment of bulk tissue, sponge cells, and microbial cells, 1-way PERMANOVA analyses were performed for $\delta^{13} \mathrm{C}$ and $\delta^{15} \mathrm{~N}$ independently, per species. Monte Carlo pairwise comparisons were made to determine which levels of treatment time-point were significant. For each species, 1-way PERMANOVAs were conducted to test for differences in the molar $\mathrm{C}: \mathrm{N}$ ratio of enriched sponge cell and microbial fractions. Resemblance matrices were constructed using Euclidean distances and tests performed using Type III sum of squares and unrestricted permutation of raw data (999 permutations). Significance was determined at the $\alpha=0.05$ level. See Table 1 for full statistical output.

\section{RESULTS}

\subsection{Incorporation of DOM into bulk sponge tissue, host cells, and symbiotic microbes}

The sponges Haliclona vansoesti and Scopalina ruetzleri displayed significant enrichment of DOMderived ${ }^{13} \mathrm{C}$ and ${ }^{15} \mathrm{~N}$ into their bulk tissue, host cells, and symbiotic microbes during the $3 \mathrm{~h}$ pulse (PERMANOVA pairwise tests $T_{0}$ vs. $T_{3}$, all $\mathrm{p}_{(\mathrm{MC})}<0.05$; Table 1, Fig. 3). Stable isotopic enrichment of bulk sponge tissue after the pulse period translated to DOM incorporation rates of $1.11 \pm 0.04 \mu \mathrm{mol} \mathrm{C}_{\mathrm{DOM}}$ $\mathrm{mmol} \mathrm{C}_{\text {sponge }}{ }^{-1} \mathrm{~h}^{-1}$ and $1.15 \pm 0.06 \mu \mathrm{mol} \mathrm{N}_{\text {DOM }} \mathrm{mmol}$ $\mathrm{N}_{\text {sponge }}{ }^{-1} \mathrm{~h}^{-1}$ for $H$. vansoesti, and $0.73 \pm 0.07 \mu \mathrm{mol}$ $\mathrm{C}_{\text {DOM }} \mathrm{mmol} \mathrm{C}_{\text {sponge }}{ }^{-1} \mathrm{~h}^{-1}$ and $0.65 \pm 0.04 \mu \mathrm{mol}$ $\mathrm{N}_{\text {DOM }} \mathrm{mmol}_{\mathrm{N}_{\text {sponge }}}^{-1} \mathrm{~h}^{-1}$ for $S$. ruetzleri. DOM assimilation rates by sponge cells and symbiotic microbes of $S$. ruetzleri were similar, but incorporation rates by sponge cells of $H$. vansoesti were approximately 1.5to 2-fold higher than for symbiotic microbes (Table 2).

During the $21 \mathrm{~h}$ chase period, the bulk tissue, sponge cells, and symbiotic microbes of both species remained enriched in ${ }^{13} \mathrm{C}$ and ${ }^{15} \mathrm{~N}$ (Fig. 3). However, the average isotopic enrichment of both bulk sponge tissue and separated sponge cells decreased relative to the end of the $3 \mathrm{~h}$ pulse, although these trends were not significant (PERMANOVA pairwise tests $T_{3}$ vs. $T_{24}$, all $\mathrm{p}_{(\mathrm{MC})}>0.05$; Table 1, Fig. 3A,B). This was coupled with an increase in the average isotopic enrichment of microbial symbionts (Fig. 3C): 
Table 1. Results of individual 1-way PERMANOVAs testing for differences in dissolved organic matter derived ${ }^{13} \mathrm{C}$ and ${ }^{15} \mathrm{~N}$ enrichment into bulk sponge tissue, sponge cells, and microbes, between time-points $(0,3,24 \mathrm{~h})$ for the sponges Haliclona vansoesti and Scopalina ruetzleri. Pairwise (PW) comparisons using Monte Carlo tests show significant differences between each time-point. $\mathrm{p}_{(\mathrm{perm})}$ : permutational $\mathrm{p}$-value, $\mathrm{p}_{(\mathrm{MC})}$ : Monte Carlo permutational $\mathrm{p}$-value. Values in bold are statistically significant $(\mathrm{p}<0.05)$

\begin{tabular}{|c|c|c|c|c|c|c|c|c|c|c|c|}
\hline \multirow[t]{2}{*}{ Sample } & & \multicolumn{5}{|c|}{ - PERMANOVA main test } & \multirow{2}{*}{$\begin{array}{l}\text { PW tests } \\
\text { Groups }\end{array}$} & \multicolumn{2}{|c|}{ - Carbon -} & \multicolumn{2}{|c|}{ _ Nitrogen - } \\
\hline & & df & SS & MS & Pseudo- $F$ & $\mathrm{p}_{(\text {perm })}$ & & $t$ & $\mathrm{p}_{(\mathrm{MC})}$ & $t$ & $\mathrm{p}_{(\mathrm{MC})}$ \\
\hline \multicolumn{12}{|l|}{ H. vansoesti } \\
\hline \multirow{3}{*}{$\begin{array}{l}\text { Bulk } \\
\text { tissue }\end{array}$} & $\mathrm{C}$ & 2,6 & 29414 & 14707 & 24.82 & 0.005 & 0 vs. $3 \mathrm{~h}$ & 51.78 & 0.0001 & 31.40 & $<0.001$ \\
\hline & $\mathrm{N}$ & 2,6 & 28845 & 14423 & 33.055 & 0.003 & 0 vs. $24 \mathrm{~h}$ & 3.671 & 0.0233 & 4.361 & 0.013 \\
\hline & & & & & & & 3 vs. $24 \mathrm{~h}$ & 2.027 & 0.1192 & 2.273 & 0.084 \\
\hline \multirow{3}{*}{$\begin{array}{l}\text { Sponge } \\
\text { cells }\end{array}$} & $\mathrm{C}$ & 2,6 & 91539 & 45770 & 21.366 & 0.008 & 0 vs. $3 \mathrm{~h}$ & 8.455 & 0.0018 & 9.515 & $<0.001$ \\
\hline & $\mathrm{N}$ & 2,6 & 94065 & 47032 & 23.249 & 0.007 & 0 vs. $24 \mathrm{~h}$ & 4.581 & 0.0096 & 4.041 & 0.013 \\
\hline & & & & & & & 3 vs. $24 \mathrm{~h}$ & 1.602 & 0.1867 & 2.248 & 0.088 \\
\hline \multirow[t]{3}{*}{ Microbes } & $\mathrm{C}$ & 2,6 & 47098 & 23549 & 24.599 & 0.018 & 0 vs. $3 \mathrm{~h}$ & 11.67 & 0.0005 & 9.032 & 0.001 \\
\hline & $\mathrm{N}$ & 2,6 & 66585 & 33292 & 22.505 & 0.008 & 0 vs. $24 \mathrm{~h}$ & 5.732 & 0.0057 & 5.815 & 0.004 \\
\hline & & & & & & & 3 vs. $24 \mathrm{~h}$ & 0.704 & 0.5179 & 2.357 & 0.083 \\
\hline $\mathrm{C}: \mathrm{N}$ ratio & & 1,10 & 47.12 & 47.11 & 48.816 & 0.002 & & & & & \\
\hline \multicolumn{12}{|l|}{ S. ruetzleri } \\
\hline Bulk & $\mathrm{C}$ & 2,6 & 13593 & 6796.6 & 12.523 & 0.014 & 0 vs. $3 \mathrm{~h}$ & 19.13 & 0.0001 & 27.40 & $<0.001$ \\
\hline \multirow[t]{2}{*}{ tissue } & $\mathrm{N}$ & 2,6 & 97976 & 48988 & 21.64 & 0.016 & 0 vs. $24 \mathrm{~h}$ & 3.029 & 0.0397 & 3.949 & 0.017 \\
\hline & & & & & & & 3 vs. $24 \mathrm{~h}$ & 0.953 & 0.3954 & 1.279 & 0.269 \\
\hline \multirow{3}{*}{$\begin{array}{l}\text { Sponge } \\
\text { cells }\end{array}$} & $\mathrm{C}$ & 2,6 & 24421 & 12211 & 5.9882 & 0.072 & 0 vs. $3 \mathrm{~h}$ & 3.546 & 0.0244 & 3.641 & 0.024 \\
\hline & $\mathrm{N}$ & 2,6 & 11167 & 55834 & 6.8729 & 0.032 & 0 vs. $24 \mathrm{~h}$ & 3.358 & 0.0279 & 3.743 & 0.02 \\
\hline & & & & & & & 3 vs. $24 \mathrm{~h}$ & 0.191 & 0.859 & 0.427 & 0.694 \\
\hline \multirow[t]{3}{*}{ Microbes } & $\mathrm{C}$ & 2,6 & 31927 & 15963 & 10.227 & 0.011 & 0 vs. $3 \mathrm{~h}$ & 5.204 & 0.0075 & 11.73 & $<0.001$ \\
\hline & $\mathrm{N}$ & 2,6 & 44848 & 22424 & 19.816 & 0.002 & 0 vs. $24 \mathrm{~h}$ & 4.046 & 0.0136 & 5.206 & 0.006 \\
\hline & & & & & & & 3 vs. $24 \mathrm{~h}$ & 1.476 & 0.2154 & 2.972 & 0.04 \\
\hline C:N ratio & & 1,10 & 12.79 & 12.79 & 150.14 & 0.003 & & & & & \\
\hline
\end{tabular}
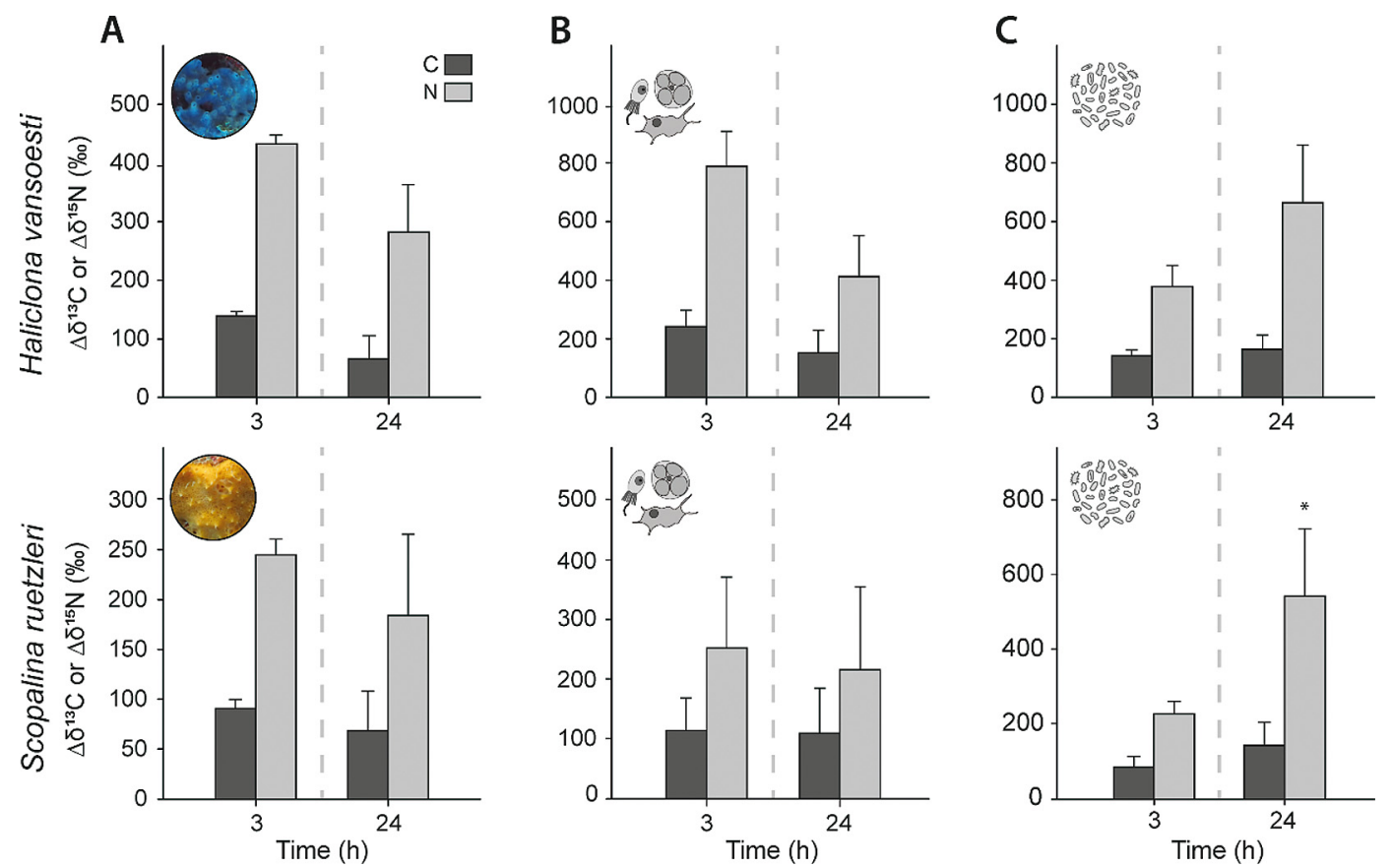

Fig. 3. Isotopic enrichment of (A) bulk sponge tissue, (B) sponge cells, and (C) symbiotic microbes of the sponges Haliclona vansoesti and Scopalina ruetzleri after a $3 \mathrm{~h}$ pulse of isotopically labelled $\left({ }^{13} \mathrm{C}\right.$ and $\left.{ }^{15} \mathrm{~N}\right)$ dissolved organic matter. Dashed grey lines: the end of the $3 \mathrm{~h}$ pulse and beginning of the $21 \mathrm{~h}$ chase. Enrichment presented as mean \pm SD relative to non-labelled controls $\left(\Delta \delta^{13} \mathrm{C}\right.$ and $\left.\Delta \delta^{15} \mathrm{~N}\right)$. Significant differences $\left({ }^{*} \mathrm{p}<0.05\right)$ between the end of the pulse $(3 \mathrm{~h})$ and chase $(24 \mathrm{~h})$ period are indicated. Note the different $y$-axis scales between graphs 
Table 2. Incorporation rates of carbon and nitrogen into bulk tissue, host cells, and microbial symbionts of 3 individuals of the sponge species Haliclona vansoesti $(\mathrm{Hv})$ and Scopalina ruetzleri $(\mathrm{Sr})$ during the $3 \mathrm{~h}$ pulse of isotopically labelled dissolved organic matter (DOM). Rates are expressed as $\mu \mathrm{mol}$ $\mathrm{C}_{\text {DOM }} \mathrm{mmol} \mathrm{C}_{\text {fraction }}{ }^{-1} \mathrm{~h}^{-1}$ and $\mu \mathrm{mol} \mathrm{N}_{\text {DOM }}$ mmol $\mathrm{N}_{\text {fraction }}{ }^{-1} \mathrm{~h}^{-1}$, where fraction represents bulk sponge tissue, sponge cells, or microbial symbionts

\begin{tabular}{|c|c|c|c|c|c|c|}
\hline & $\begin{array}{c}\text { Bulk } \\
\text { tissue }\end{array}$ & $\begin{array}{c}\text { - Carbor } \\
\text { Sponge } \\
\text { cells }\end{array}$ & Microbes & $\begin{array}{c}\text { Bulk } \\
\text { tissue }\end{array}$ & $\begin{array}{c}\text { - Nitroge } \\
\text { Sponge } \\
\text { cells }\end{array}$ & $\begin{array}{l}\text { en } \\
\text { e Microbes }\end{array}$ \\
\hline$H v 1$ & 1.13 & 2.30 & 1.32 & 1.21 & 2.44 & 1.22 \\
\hline Hv 2 & 1.13 & 1.52 & 0.98 & 1.14 & 1.68 & 0.85 \\
\hline$H_{v} 3$ & 1.07 & 1.99 & 1.11 & 1.09 & 2.14 & 0.94 \\
\hline Sr 1 & 0.81 & 1.43 & 0.95 & 0.70 & 1.03 & 0.71 \\
\hline Sr 2 & 0.68 & 0.76 & 0.63 & 0.62 & 0.57 & 0.55 \\
\hline Sr 3 & 0.72 & 0.57 & 0.51 & 0.63 & 0.42 & 0.56 \\
\hline
\end{tabular}

${ }^{13} \mathrm{C}$-enrichment increased from $141 \pm 21$ to $163 \pm$ $49 \%$ or $H$. vansoesti and from $87 \pm 29$ to $145 \pm 62 \%$ for $S$. ruetzleri. The increases in ${ }^{15} \mathrm{~N}$-enrichment were larger, with values increasing from $377 \pm 72$ to $664 \pm 198 \%$ for $H$. vansoesti and from $230 \pm 34$ to 546 $\pm 181 \%$ for $S$. ruetzleri. The overall trend of loss of stable isotope tracer in the bulk and sponge cell fractions coupled with a gain in the symbiont fraction during the label-free chase period indicates translocation of DOM-derived $\mathrm{C}$ and $\mathrm{N}$ from host cells to microbial symbionts. However, this trend was only significant for the increase in average ${ }^{15} \mathrm{~N}$-enrichment of symbiotic microbes of $S$. ruetzleri (PERMANOVA pairwise test $T_{3}$ Vs. $T_{24}, t=2.97, \mathrm{p}_{(\mathrm{MC})}=0.04$ ).

\subsection{Contribution of host cells and symbionts to DOM uptake}

Despite similar DOM-derived C and N incorporation rates by sponge cells and microbial symbionts of both species, sponge cells accounted for the majority (>99\%) of DOM assimilation during the pulse-chase experiment when differences in cellular biomass and abundance between fractions were considered (Fig. 4). Host cells dominate the cellular biomass of these LMA species, whilst their sparse microbial communities comprise small cells $\leq 0.5 \mu$ m diameter (Fig. 1B,D). Symbiotic microbes of $H$. vansoesti assimilated $0.17 \%$ of the total DOC and $0.12 \%$ of the total DON during the $3 \mathrm{~h}$ pulse. Similarly, symbiotic microbes of $S$. ruetzleri assimilated 0.29 and $0.32 \%$ of the total DOC and DON during the pulse, respectively. In conjunction with the isotopic enrichment results (Fig. 3B,C), the decrease in ${ }^{13} \mathrm{C}$ - and ${ }^{15} \mathrm{~N}$-enrich-

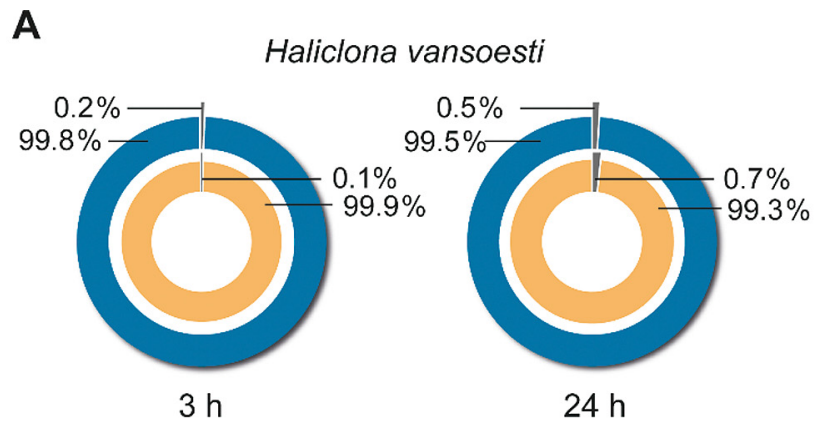

B

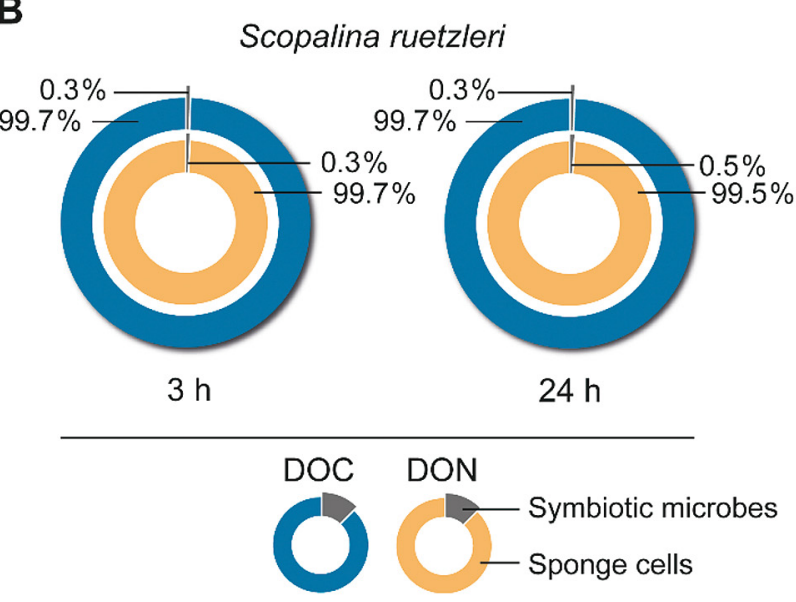

Fig. 4. Relative contribution of sponge cells and microbial symbionts of the sponges (A) Haliclona vansoesti and (B) Scopalina ruetzleri to total dissolved organic matter assimilation. Shown are the average contributions of each cell fraction at the end of the pulse $(3 \mathrm{~h})$ and chase $(24 \mathrm{~h})$ period $(n=3)$. DOC: dissolved organic carbon; DON: dissolved organic nitrogen

ment of sponge cells and increase in symbiotic microbes resulted in a small increase in the relative contribution of microbial assimilation to total DOC and DON assimilation during the $21 \mathrm{~h}$ chase (Fig. 4). Microbial enrichment as a percentage of total enrichment increased from 0.17 to $0.52 \%$ for DOC and 0.12 to $0.69 \%$ for DON in $H$. vansoesti, and from 0.29 to $0.31 \%$ for DOC and 0.32 to $0.52 \%$ for DON in S. ruetzleri, between 3 and 24 h (Fig. 4).

\section{DISCUSSION}

Sponges have been traditionally viewed as 'particle feeders', with phagocytosis as the primary mechanism of food uptake (van Tright 1919, van Weel 1949, Hahn-Keser \& Stockem 1997, Steinmetz 2019). Over the past few decades, the paradigm of sponge feeding ecology has shifted to also include sponges as 'solute feeders', as it has become clear that DOM 
is a major component of the diet of many sponges (e.g. Reiswig 1981, Yahel et al. 2003, de Goeij et al. 2017, Wooster et al. 2019). Studies investigating the relative contribution of sponge host and microbiome to DOM uptake and the subsequent exchange of nutrients, however, are limited (Achlatis et al. 2019, Rix et al. 2020, Hudspith et al. 2021). Here, we found that although both host and symbiont cells assimilated DOM, N-rich compounds derived from DOM were translocated from sponge cells to symbiotic microbes of the encrusting sponges Haliclona vansoesti and Scopalina ruetzleri over time, indicating utilization of nitrogenous wastes of the host by the microbiome. Host cells were primarily responsible for DOM uptake in these species, while microbial symbionts played a quantitatively minor role in this process, demonstrating the ability of sponge cells to internalize fluids and effectively exploit the largest source of organic C in the ocean: DOM. Despite not contributing significantly to heterotrophic nutrient acquisition in the LMA sponges tested here, microbial symbionts can nevertheless fulfil functionally important roles within the holobiont (Weisz et al. 2010, Fan et al. 2012, Song et al. 2021), which may explain in part the long-term stability and specificity of sponge-microbe symbioses.

\subsection{Translocation of DOM-derived N from host cells to microbial symbionts}

Both host cells and microbial symbionts incorporated DOM during the $3 \mathrm{~h}$ pulse, with microbial enrichment possibly resulting from direct or hostmediated uptake. During the chase period, $\mathrm{N}$ derived from DOM was translocated from host cells to the microbiome of both species, as ${ }^{15} \mathrm{~N}$-enrichment of symbiotic microbes increased during the label-free chase, while host-cell enrichment decreased. The trend of increasing microbial ${ }^{15} \mathrm{~N}$-enrichment over time was statistically significant for $S$. ruetzleri but not for $H$. vansoesti, which may be due to low statistical power (only 3 replicates per species, per timepoint), or inter-specific differences in the exchange of N-rich compounds between host cells and symbionts. The incorporation of these metabolites by the microbial community indicates recycling of nitrogenous wastes. Numerous molecular studies have highlighted the potential of the sponge microbiome to assimilate ammonium (Thomas et al. 2010, Feng et al. 2018), urea (Su et al. 2013), nitrate/nitrite (via assimilatory nitrate reduction; Weigel \& Erwin 2017), and creatine/creatinine (Moitinho-Silva et al. 2017a), and microbial communities of sponges have recently been shown to incorporate $\mathrm{N}$ derived from host DOM-feeding (Achlatis et al. 2019, Hudspith et al. 2021). Together, these findings show that microbial symbionts benefit from their association with the host in a commensal manner, but do not exclude reciprocal benefits for the host. Aside from eliminating metabolites that are potentially toxic to the host (e.g. ammonia), the utilization of metabolic waste by microbial symbionts aids in the retention of nutrients that would otherwise be expelled from the sponge. This process would be advantageous for sponges, particularly in the oligotrophic environments in which they typically thrive. The metabolic waste that fertilizes microbial communities can be further recycled back to the host via phagocytosis of symbionts by host cells (Leys et al. 2018), microbial degradation and subsequent resorption, or extracellular release, thereby conferring mutual benefits to both partners. By including an extended chase period (e.g. $>48$ h), further work could confirm these translocation dynamics, which may take longer to manifest than our experimental timeframe allowed.

\subsection{Host cells drive DOM uptake in $H$. vansoesti and $S$. ruetzleri}

Sponge cells are principally responsible for DOM uptake in the LMA species $H$. vansoesti and $S$. ruetzleri, accounting for $>99 \%$ of total DOC and DON incorporation. These findings are similar to those of Rix et al. (2020), who found sponge cells of the Mediterranean LMA sponge Dysidea avara were responsible for $99.6 \%$ of DOC uptake and $98.6 \%$ of DON uptake when fed algal-derived DOM. The similarities in host cell contribution to DOM uptake between a massive sponge and our encrusting species strengthens the hypothesis of host-driven uptake in LMA sponges. Further studies are needed to determine if this strategy is conserved across species with different growth forms from different habitats and for HMA species, where microbes can constitute up to $40 \%$ of sponge biomass (Hentschel et al. 2003). To date, the only HMA species examined showed a much larger contribution by symbiotic microbes, which reflects differing host-symbiont strategies for DOM uptake (Rix et al. 2020). Choanocytes are the main digestive cell type in sponges and are primarily responsible for DOM uptake (Achlatis et al. 2019, Hudspith et al. 2021). While the cellular mechanism of DOM incorporation by choanocytes is not known, small molecules, such as amino acids or sugar monomers, can 
traverse eukaryotic membranes via transporter proteins, and genes coding for membrane transporters (e.g. amino acids, vitamins) have been identified in sponges (Fiore et al. 2015, Sogabe et al. 2019). Larger molecules are internalized via endocytosis, which is broadly divided into phagocytosis and pinocytosis, depending on particle size. Fluids and dissolved compounds are absorbed via pinocytosis ('cell drinking'), which encompasses macropinocytosis and clathrin- and caveolae-dependent/independent pathways (Conner \& Schmid 2003). Evidence for macropinocytic activity has been found in freshwater (Hahn-Keser \& Stockem 1997, Musser et al. preprint doi:10.1101/758276) and marine sponges (Laundon et al. 2019). In corals, macropinocytosis is a major endocytic pathway and occurs across many cell types, facilitating solute absorption from the environment (Ganot et al. 2020). Further studies characterizing the cellular mechanism of DOM uptake by sponge cells and the degree of reliance of symbiont DOM assimilation on transport by choanocytes will help define the interdependency of DOM-fuelled sponge-symbiont interactions. Symbiotic microbes reside within the sponge mesohyl — the gelatinous matrix bound by the external pinacoderm and internal choanosome-and thus dissolved compounds theoretically have to pass through either of these cell layers before they can be utilized by microbes. Investigating host control over symbiont access to DOM will be especially pertinent in HMA sponges, where symbionts can contribute significantly (>65\%) to DOM assimilation (Rix et al. 2020).

The low contribution $(<1 \%)$ of the microbiome of $H$. vansoesti and $S$. ruetzleri to DOM assimilation, driven by their low relative biomass, suggests that microbial symbionts do not facilitate ecological niche expansion with respect to DOM cycling in these LMA species. However, microbial symbionts bring other, unique metabolic capabilities to their sponge host. Both $H$. vansoesti and $S$. ruetzleri harbor cyanobacteria (Easson \& Thacker 2014, Rua et al. 2015), and although we observed few cyanobacteria in the homogenate of these sponges during the cell separation process, they can nevertheless provide supplemental host nutrition via the translocation of photosynthetically fixed C (Wilkinson 1979). Proteobacteria is an abundant bacterial group in these species (Gamma- and Alpha-proteobacteria for $H$. vansoesti and S. ruetzleri, respectively) (Easson \& Thacker 2014, Rua et al. 2015) and is amongst the most dominant phylum in sponge microbiomes, particularly in LMA species (Giles et al. 2013, MoitinhoSilva et al. 2017b). They have been linked to a variety of functions, including nutrient transport, C metabolism (Moitinho-Silva et al. 2014), sulphur metabolism (Karimi et al. 2018), and inorganic phosphate assimilation (Gauthier et al. 2016). Aside from nutrition exchange, sponge symbionts can also benefit their host via photoprotection (Regoli et al. 2000), chemical defense (see Selvin et al. 2010), and utilization of potentially toxic metabolites.

\subsection{Evaluating sponge heterotroph-heterotroph symbioses using host-symbiont cell separation}

Here, we utilized sponge-microbe cell separation to successfully partition nutrient uptake and detect low levels of nutrient exchange within sponge heterotroph-heterotroph symbioses. Previous studies have attempted to infer host-symbiont partitioning of DOM using phospholipid fatty acid (PLFA) SIP (Rix et al. 2017, Bart et al. 2020, Campana et al. 2021). However, this approach only considers the fraction of DOM incorporated into PLFAs, and only a relatively small number of PLFAs can be identified as bacterial- or sponge-specific biomarkers. Furthermore, short incubation times were hypothesized to be insufficient for the synthesis of very long-chained sponge-specific PLFAs, which limits interpretation of the data (Bart et al. 2020, Campana et al. 2021). Cellseparation enables a fully quantitative evaluation of host-symbiont uptake and translocation, as it includes DOM assimilation into total cellular biomass. This method requires optimization per species to obtain good separation of the host and symbiont fractions, which can be challenging and may not be practical for all species. We trialed a range of encrusting species, including HMA sponges, but found many were not suitable for the method (e.g. Halisarca caerulea, Chondrilla caribensis, Plakortis angulospiculatus, Hyrtios proteus). Due to their smaller sizes and the ease with which they can be shaped into fully functional individuals, encrusting species are ideal candidates for SIP experiments compared with massive species. Factors such as tissue density and composition, symbiont community (e.g. the presence of large cyanobacteria or eukaryotic symbionts such as dinoflagellates), and cell aggregation (e.g. both host-host and host-microbe), affect whether tissue can be dissociated easily and cell fractions separated and purified. Species with dense, collagenous tissue and those containing symbionts and host cells with similar or overlapping sizes pose particular challenges and would require additional optimization steps. Nevertheless, this technique has been 
successfully used in a range of sponge species to infer trophic relationships between sponges and symbionts using natural stable-isotopic signatures of separated fractions (Freeman \& Thacker 2011, Shih et al. 2020), and to follow the transfer of symbiontderived inorganic $\mathrm{C}$ and $\mathrm{N}$ to host cells (Fiore et al. 2013, Freeman et al. 2013).

The molar C:N ratios of our sponge cell and microbial fractions were significantly different, indicating good separation of the fractions (Fiore et al. 2013, Shih et al. 2020), but a degree of cross-contamination does occur. However, similar values for host/symbiont contributions to DOM uptake were found in D. avara and Aplysina aerophoba using cell-separation and NanoSIMS (Rix et al. 2020), confirming the validity of the cell-separation technique. Our translocation results also corroborate recent studies which found DOM-derived nutrient exchange from host to microbiome using NanoSIMS (Achlatis et al. 2019, Hudspith et al. 2021), proving that host-symbiont cell separation can be a useful and sensitive tool to complement low-throughput and costly single-cell techniques.

\subsection{Future directions}

The relative contribution of symbiotic microbes to DOM assimilation increased over time in both $H$. vansoesti and S. ruetzleri (Fig. 4), which resulted from the translocation of metabolites from sponge cells to symbionts, but may also include higher retention of incorporated DOM by microbial symbionts relative to sponge cells. In order to fully quantify translocation and characterize the flow of $\mathrm{C}$ and $\mathrm{N}$ in sponge symbioses, however, a combinatorial approach is needed. Long-term isotopic labelling experiments coupled with sophisticated isotope-mixing models (Tanaka et al. 2018) can quantify nutrient cycling in holobionts, and require key aspects of sponge $\mathrm{C}$ and $\mathrm{N}$ metabolism, including proliferation rates of symbiotic microbes and release rates of $\mathrm{C}$ and $\mathrm{N}$ by the holobiont (e.g. using InEx methods; Yahel et al. 2005), to be elucidated. When combined with manipulative experiments, these models can quantify the effect of environmental stressors on nutrient acquisition and allocation within symbioses (Tremblay et al. 2013). Future studies should investigate the partitioning and exchange of nutrients in HMA and LMA sponges, and how these symbioses shift along the mutualismparasitism continuum in response to environmental change.
Acknowledgements. We thank Sara Campana and the staff at the CARMABI Research Foundation for their assistance during field work; Martijn Bart for his assistance in culturing and extracting labelled DOM; Nicole van der Wel, Edwin Scholl and the staff at the EMCA for help with sample processing and TEM. This study was funded by the European Research Council under the European Union's Horizon 2020 research and innovation programme (Starting Grant agreement number 715513 to J.M.dG.).

\section{LITERATURE CITED}

Achlatis M, Pernice M, Green K, de Goeij JM and others (2019) Single-cell visualization indicates direct role of sponge host in uptake of dissolved organic matter. Proc R Soc B 286:20192153

Anderson MJ, Gorley RN, Clarke KR (2008) PERMANOVA+ for PRIMER: guide to software and statistical methods. Primer-E, Plymouth

Azam F, Fenchel T, Field JG, Gray JS, Meyer-Reil LA, Thingstad F (1983) The ecological role of water-column microbes in the sea. Mar Ecol Prog Ser 10:257-263

Bart MC, de Kluijver A, Hoetjes S, Absalah S and others (2020) Differential processing of dissolved and particulate organic matter by deep-sea sponges and their microbial symbionts. Sci Rep 10:17515

* Bart MC, Mueller B, Rombouts T, van de Ven C and others (2021) Dissolved organic carbon (DOC) is essential to balance the metabolic demands of four dominant NorthAtlantic deep-sea sponges. Limnol Oceanogr 66:925-938

* Benner R, Pakulski JD, McCarthy M, Hedges JI, Hatcher PG (1992) Bulk chemical characteristics of dissolved organic matter in the ocean. Science 255:1561-1564

* Campana S, Hudspith M, Lankes D, de Kluijver A and others (2021) Processing of naturally sourced macroalgaland coral-dissolved organic matter (DOM) by high and low microbial abundance encrusting sponges. Front Mar Sci 8:452

* Cavanaugh CM, Gardiner SL, Jones ML, Jannasch HW, Waterbury JB (1981) Prokaryotic cells in the hydrothermal vent tube worm Riftia pachyptila Jones: possible chemoautotrophic symbionts. Science 213:340-342

Clarke KR, Gorley RN (2015) PRIMER v7: user manual/tutorial. Primer-E, Plymouth

Conner SD, Schmid SL (2003) Regulated portals of entry into the cell. Nature 422:37-44

de Goeij JM, van Duyl FC (2007) Coral cavities are sinks of dissolved organic carbon (DOC). Limnol Oceanogr 52: 2608-2617

* de Goeij JM, Moodley L, Houtekamer M, Carballeira NM, van Duyl FC (2008) Tracing ${ }^{13} \mathrm{C}$-enriched dissolved and particulate organic carbon in the bacteria-containing coral reef sponge Halisarca caerulea: evidence for DOMfeeding. Limnol Oceanogr 53:1376-1386

de Goeij JM, de Kluijver A, van Duyl FC, Vacelet J and others (2009) Cell kinetics of the marine sponge Halisarca caerulea reveal rapid cell turnover and shedding. J Exp Biol 212:3892-3900

* de Goeij JM, van Oevelen D, Vermeij MJA, Osinga R, Middelburg JJ, de Goeij AFPM, Admiraal W (2013) Surviving in a marine desert: the sponge loop retains resources within coral reefs. Science 342:108-110

de Goeij JM, Lesser MP, Pawlik JR (2017) Nutrient fluxes and ecological functions of coral reef sponges in a 
changing ocean. In: Carballo JL, Bell JJ (eds) Climate change, ocean acidification and sponges. Springer, Cham, p 373-410

Ducklow HW, Carlson CA (1992) Oceanic bacterial production. In: Marshall KC (ed) Advances in microbial ecology, Vol 12. Springer, Boston, MA, p 113-181

Easson CG, Thacker RW (2014) Phylogenetic signal in the community structure of host-specific microbiomes of tropical marine sponges. Front Microbiol 5:532

Erwin PM, Pita L, López-Legentil S, Turon X (2012) Stability of sponge-associated bacteria over large seasonal shifts in temperature and irradiance. Appl Environ Microbiol 78:7358-7368

Fan L, Reynolds D, Liu M, Stark M, Kjelleberg S, Webster NS, Thomas T (2012) Functional equivalence and evolutionary convergence in complex communities of microbial sponge symbionts. Proc Natl Acad Sci USA 109: E1878-E1887

Feng G, Sun W, Zhang F, Orlić S, Li Z (2018) Functional transcripts indicate phylogenetically diverse active ammonia-scavenging microbiota in sympatric sponges. Mar Biotechnol (NY) 20:131-143

Fiore CL, Baker DM, Lesser MP (2013) Nitrogen biogeochemistry in the Caribbean sponge, Xestospongia muta: A source or sink of dissolved inorganic nitrogen? PLOS ONE 8:e72961

Fiore CL, Labrie M, Jarett JK, Lesser MP (2015) Transcriptional activity of the giant barrel sponge, Xestospongia muta holobiont: molecular evidence for metabolic interchange. Front Microbiol 6:364

Freeman CJ, Thacker RW (2011) Complex interactions between marine sponges and their symbiotic microbial communities. Limnol Oceanogr 56:1577-1586

Freeman CJ, Thacker RW, Baker DM, Fogel ML (2013) Quality or quantity: Is nutrient transfer driven more by symbiont identity and productivity than by symbiont abundance? ISME J 7:1116-1125

* Ganot P, Tambutté E, Caminiti-Segonds N, Toullec G, Allemand D, Tambutté S (2020) Ubiquitous macropinocytosis in anthozoans. eLife 9:e50022

*Gauthier MEA, Watson JR, Degnan SM (2016) Draft genomes shed light on the dual bacterial symbiosis that dominates the microbiome of the coral reef sponge Amphimedon queenslandica. Front Mar Sci 3:196

* Giles EC, Kamke J, Moitinho-Silva L, Taylor MW, Hentschel U, Ravasi T, Schmitt S (2013) Bacterial community profiles in low microbial abundance sponges. FEMS Microbiol Ecol 83:232-241

Hahn-Keser B, Stockem W (1997) Detection of distinct endocytotic and phagocytotic activities in epithelial cells (pinacocytes) of freshwater sponges (Porifera, Spongillidae). Zoomorphology 117:121-134

Hay ME, Parker JD, Burkepile DE, Caudill CC, Wilson AE, Hallinan ZP, Chequer AD (2004) Mutualisms and aquatic community structure: the enemy of my enemy is my friend. Annu Rev Ecol Evol Syst 35:175-197

Hentschel U, Fieseler L, Wehrl M, Gernert C, Steinert M, Hacker J, Horn M (2003) Microbial diversity of marine sponges. In: Müller WEG (ed) Sponges (Porifera). Springer, Berlin Heidelberg, p 59-88

Hoer DR, Gibson PJ, Tommerdahl JP, Lindquist NL, Martens CS (2018) Consumption of dissolved organic carbon by Caribbean reef sponges. Limnol Oceanogr 63:337-351

Hudspith M, Rix L, Achlatis M, Bougoure J and others (2021) Subcellular view of host-microbiome nutrient exchange in sponges: insights into the ecological success of an early metazoan-microbe symbiosis. Microbiome 9:44

KKahn AS, Yahel G, Chu JW, Tunnicliffe V, Leys SP (2015) Benthic grazing and carbon sequestration by deep-water glass sponge reefs. Limnol Oceanogr 60:78-88

Karimi E, Slaby BM, Soares AR, Blom J, Hentschel U, Costa $R$ (2018) Metagenomic binning reveals versatile nutrient cycling and distinct adaptive features in alphaproteobacterial symbionts of marine sponges. FEMS Microbiol Ecol 94:fiy074

Kornder NA, Cappelletto J, Mueller B, Zalm MJL and others (2021) Implications of 2D versus 3D surveys to measure the abundance and composition of benthic coral reef communities. Coral Reefs, doi.org/10.1007/s00338-021-02118-6

* Laundon D, Larson BT, McDonald K, King N, Burkhardt P (2019) The architecture of cell differentiation in choanoflagellates and sponge choanocytes. PLOS Biol 17:e3000226

Leung TLF, Poulin R (2008) Parasitism, commensalism, and mutualism: exploring the many shades of symbioses. Vie Milieu 58:107-115

* Leys SP, Kahn AS, Fang JKH, Kutti T, Bannister RJ (2018) Phagocytosis of microbial symbionts balances the carbon and nitrogen budget for the deep-water boreal sponge Geodia barretti. Limnol Oceanogr 63:187-202

* McMurray SE, Johnson ZI, Hunt DE, Pawlik JR, Finelli CM (2016) Selective feeding by the giant barrel sponge enhances foraging efficiency. Limnol Oceanogr 61: 1271-1286

Moitinho-Silva L, Seridi L, Ryu T, Voolstra CR, Ravasi T, Hentschel U (2014) Revealing microbial functional activities in the Red Sea sponge Stylissa carteri by metatranscriptomics. Environ Microbiol 16:3683-3698

Koitinho-Silva L, Díez-Vives C, Batani G, Esteves AI, Jahn MT, Thomas T (2017a) Integrated metabolism in spongemicrobe symbiosis revealed by genome-centered metatranscriptomics. ISME J 11:1651-1666

*Moitinho-Silva L, Steinert G, Nielsen S, Hardoim CCP and others (2017b) Predicting the HMA-LMA status in marine sponges by machine learning. Front Microbiol 8:752

*Morganti T, Coma R, Yahel G, Ribes M (2017) Trophic niche separation that facilitates co-existence of high and low microbial abundance sponges is revealed by in situ study of carbon and nitrogen fluxes. Limnol Oceanogr 62: 1963-1983

Muscatine L, Porter JW (1977) Reef corals: mutualistic symbioses adapted to nutrient-poor environments. Bioscience 27:454-460

Paracer S, Ahmadjian V (2000) Symbiosis: an introduction to biological associations. Oxford University Press, New York, NY

* Regoli F, Cerrano C, Chierici E, Bompadre S, Bavestrello G (2000) Susceptibility to oxidative stress of the Mediterranean demosponge Petrosia ficiformis : role of endosymbionts and solar irradiance. Mar Biol 137:453-461

* Reiswig HM (1981) Partial carbon and energy budgets of the bacteriosponge Verongia fistularis (Porifera: Demospongiae) in Barbados. Mar Ecol 2:273-293

* Reveillaud J, Maignien L, Eren MA, Huber JA, Apprill A, Sogin ML, Vanreusel A (2014) Host-specificity among abundant and rare taxa in the sponge microbiome. ISME J 8:1198-1209

Rix L, de Goeij JM, van Oevelen D, Struck U, Al-Horani F, Wild C, Naumann MS (2017) Differential recycling of coral and algal dissolved organic matter via the sponge loop. Funct Ecol 31:778-789 
Rix L, Ribes M, Coma R, Jahn MT and others (2020) Heterotrophy in the earliest gut: a single-cell view of heterotrophic carbon and nitrogen assimilation in spongemicrobe symbioses. ISME J 14:2554-2567

Rua CPJ, Gregoracci GB, Santos EO, Soares AC, FranciniFilho RB, Thompson F (2015) Potential metabolic strategies of widely distributed holobionts in the oceanic archipelago of St Peter and St Paul (Brazil). FEMS Microbiol Ecol 91:fiv043

Rubin-Blum M, Antony CP, Sayavedra L, Martínez-Pérez C and others (2019) Fueled by methane: deep-sea sponges from asphalt seeps gain their nutrition from methaneoxidizing symbionts. ISME J 13:1209-1225

Schmitt S, Tsai P, Bell J, Fromont J and others (2012) Assessing the complex sponge microbiota: core, variable and species-specific bacterial communities in marine sponges. ISME J 6:564-576

Selvin J, Ninawe AS, Seghal Kiran G, Lipton AP (2010) Sponge-microbial interactions: ecological implications and bioprospecting avenues. Crit Rev Microbiol 36:82-90

Shih JL, Selph KE, Wall CB, Wallsgrove NJ, Lesser MP, Popp BN (2020) Trophic ecology of the tropical Pacific sponge Mycale grandis inferred from amino acid compound-specific isotopic analyses. Microb Ecol 79:495-510

Shore RE (1971) Growth and renewal studies of the choanocyte population in Hymeniacidon sinapium (Porifera: Demospongiae) using colcemid and 3-H thymidine. J Exp Zool 177:359-363

Smith SE, Read DJ (2010) Mycorrhizal symbiosis. Academic Press, London

Sogabe S, Hatleberg WL, Kocot KM, Say TE and others (2019) Pluripotency and the origin of animal multicellularity. Nature 570:519-522

Song H, Hewitt OH, Degnan SM (2021) Arginine biosynthesis by a bacterial symbiont enables nitric oxide production and facilitates larval settlement in the marine-sponge host. Curr Biol 31:433-437

Steinmetz PRH (2019) A non-bilaterian perspective on the development and evolution of animal digestive systems. Cell Tissue Res 377:321-339

Su J, Jin L, Jiang Q, Sun W, Zhang F, Li Z (2013) Phylogenetically diverse ureC genes and their expression suggest the urea utilization by bacterial symbionts in marine sponge Xestospongia testudinaria. PLOS ONE 8:e64848

Tanaka Y, Suzuki A, Sakai K (2018) The stoichiometry of coral-dinoflagellate symbiosis: carbon and nitrogen cycles are balanced in the recycling and double translocation system. ISME J 12:860-868

Taylor MW, Radax R, Steger D, Wagner M (2007) Spongeassociated microorganisms: evolution, ecology, and biotechnological potential. Microbiol Mol Biol Rev 71: 295-347

Thacker RW, Freeman CJ (2012) Sponge-microbe symbioses: recent advances and new directions. Adv Mar Biol 62: $57-111$

* Thomas T, Rusch D, DeMaere MZ, Yung PY and others (2010) Functional genomic signatures of sponge bacteria reveal unique and shared features of symbiosis. ISME J 4:1557-1567

Thomas T, Moitinho-Silva L, Lurgi M, Björk JR and others

Editorial responsibility: James McClintock,

Birmingham, Alabama, USA

Reviewed by: C. Easson and 2 anonymous referees
(2016) Diversity, structure and convergent evolution of the global sponge microbiome. Nat Commun 7:11870

* Tremblay P, Fine M, Maguer JF, Grover R, Ferrier-Pagès C (2013) Photosynthate translocation increases in response to low seawater $\mathrm{pH}$ in a coral-dinoflagellate symbiosis. Biogeosciences 10:3997-4007

* van der Heide T, Govers LL, De Fouw J, Olff H and others (2012) A three-stage symbiosis forms the foundation of seagrass ecosystems. Science 336:1432-1434

van Tright $H$ (1919) Contribution to the physiology of the fresh-water sponges (Spongillidae). Tijdschr Diergeneeskd 17:1-220

van Weel PB (1949) On the physiology of the tropical fresh water sponge, Spongilla proliferens Annand; ingestion, digestion and excretion. Physiol Comp Oocol Int J Comp Physiol Ecol 1:110-126

*Webster NS, Luter HM, Soo RM, Botté ES, Simister RL, Abdo D, Whalan S (2013) Same, same but different: symbiotic bacterial associations in GBR sponges. Front Microbiol 3:444

Weerdt WH, Kluijver MJ, Gomez R (1999) Haliclona (Halichoclona) vansoesti n. sp., a new chalinid sponge species (Porifera, Demospongiae, Haplosclerida) from the Caribbean. Beaufortia 49:47-54

Wehrl M, Steinert M, Hentschel U (2007) Bacterial uptake by the marine sponge Aplysina aerophoba. Microb Ecol 53:355-365

Weigel BL, Erwin PM (2017) Effects of reciprocal transplantation on the microbiome and putative nitrogen cycling functions of the intertidal sponge, Hymeniacidon heliophila. Sci Rep 7:43247

Weisz JB, Massaro AJ, Ramsby BD, Hill MS (2010) Zooxanthellar symbionts shape host sponge trophic status through translocation of carbon. Biol Bull (Woods Hole) 219:189-197

Wilkinson CR (1979) Nutrient translocation from symbiotic cyanobacteria to coral reef sponges. In: Lévi C, BouryEsnault N (eds) Biologie des Spongiaires. Colloques Internationaux du CNRS, No. 291. Editions du Centre national de la recherche scientifique, Paris, p 373-380

Wilkinson CR, Garrone R (1980) Nutrition of marine sponges. Involvement of symbiotic bacteria in the uptake of dissolved carbon. In: Smith DC, Tiffon Y (eds) Nutrition in the lower Metazoa. Pergamon Press, Oxford, p 157-161

Wilkinson CR, Summons RE, Evans E (1999) Nitrogen fixation in symbiotic marine sponges: ecological significance and difficulties in detection. Mem Queensl Mus 44: 667-673

WWooster MK, McMurray SE, Pawlik JR, Morán XAG, Berumen ML (2019) Feeding and respiration by giant barrel sponges across a gradient of food abundance in the Red Sea. Limnol Oceanogr 64:1790-1801

* Yahel G, Sharp JH, Marie D, Häse C, Genin A (2003) In situ feeding and element removal in the symbiont-bearing sponge Theonella swinhoei: bulk DOC is the major source for carbon. Limnol Oceanogr 48:141-149

Yahel G, Marie D, Genin A (2005) InEx - a direct in situ method to measure filtration rates, nutrition, and metabolism of active suspension feeders. Limnol Oceanogr Methods 3:46-58

Submitted: March 14, 2021

Accepted: June 9, 2021

Proofs received from author(s): July 16, 2021 